\title{
Value Relevance of Earnings and Book Value: Evidence from Jordan
}

\author{
Dhiaa Shamki (Corresponding author) \\ College of Business, University Utara Malaysia \\ 06010 UUM Sintok, Kedah Darul Aman, Malaysia \\ E-mail: dhiashamki_iraq@yahoo.com \\ Azhar Abdul Rahman \\ College of Business, University Utara Malaysia \\ 06010 UUM Sintok, Kedah Darul Aman, Malaysia \\ E-mail: abuzar70@yahoo.com
}

Received: October 5, 2011

Accepted: November 14, 2011

Published: February 1, 2012

doi:10.5539/ijbm.v7n3p133

URL: http://dx.doi.org/10.5539/ijbm.v7n3p133

\begin{abstract}
This paper examines the value relevance of earnings and book value of equity (individually and in aggregate), relative to price and return models, for Jordanian industrial companies for the period 1992 to 2002. The main findings of this paper are twofold. First, relative to price model, the value relevance of both earnings and book value (individually) have increased, whilst the value relevance of earnings increased and book value became irrelevant in their combination. Secondly, relative to return model, the value relevance of earnings either individually or in aggregate has increased while that of book value has declined. Overall, it is found that earnings are more important in explaining the variance in share price and return than book value. Furthermore, the results indicate that earnings and book value individually are more value relevant in price model. In contrast, these variables in aggregate are more value relevant in return model. The study shows that earnings help more in explaining market values in Jordanian industrial companies. This paper is the first in using price and return models in one study in Jordan.
\end{abstract}

Keywords: Price and return models, Value relevance, Earnings, Book value and Jordan

\section{Introduction}

Many decades ago, the early studies have focused on earnings (Chen, Chen and $\mathrm{Su}, 2001$ ), while the recent ones have turned their attention to include book value of equity (Pirie and Smith, 2008). A lot of studies on the relationship between stock price or return and the accounting variables have been done and similar or different results have been conducted.

Examining this relationship tends to extract information that could be considered as a relevant one. The term value relevance has been used in literature to extract the ability of accounting information to summarize information that affects stock values (Francis and Schipper, 1999). While research on the value relevance of the accounting information has focused on the developed markets in Northern America and Europe, developing markets especially in the Middle East countries have been neglected (Al-Akra, Ali and Marashdeh, 2009; Anandarajan and Hasan, 2010).

Focusing more on developed markets than developing ones resulted in deficient understanding the differences in results. Due to that academic researchers are the primary producers and intended consumers of value relevance research (Barth, Beaver, and Landsman, 2001), the paper is of academic significance in filling this gap by extending the literature to include developing countries and providing a knowledge regarding the relevancy of accounting variables as reflected in equity values.

Due to the growing focus on the role of the accounting information in the global markets in the recent years (Chen et al., 2001), recent studies have examined the value relevance of the accounting information in 
developing countries' markets (Alford, Jones, Leftwich and Zmijewski, 1993; Chen et al., 2001; Anandarajan and Hasan, 2010 among others).

This study is stimulated by the developments that occurred in the prior valuation studies. The study will expand the literature by examining the value relevance of earnings, book value of equity and a combination of them for the industrial companies listed in Amman Stock Exchange (ASE) as an emerging stock market. The current study will add further evidence about the value relevance of earnings and book value of equity in Jordan using price and return models. The question of the study is: Does the value relevance of earnings, book value of equity and their combination differ according to price and return models for Jordanian industrial companies? Addressing this question leads to indicate whether shifting from one valuation model to another yields different results for the value relevance. The study will continue by reviewing the related literature in the next section followed by the financial reporting in Jordan, hypotheses development and methodology, the empirical result and finally the summary and conclusions.

\section{Literature review}

\subsection{Price and return models}

According to the valuation theory, two valuation models are commonly used in value relevance studies namely the price and return models. Despite that they have the same theoretical foundations, their results are sometimes inconsistent (Ota, 2010).

Kothari and Zimmerman (1995) reviewed some studies that illustrate the price and return models' advantages and disadvantages. Theoretically, in the absence of well developed valuation theories, return model is superior to price model (Gonedes and Dopuch, 1974). While both models have been described as complementary (Lev and Ohlson, 1982), in some cases price model dominates return model (Landsman and Magliolo, 1988). Economically, both models are equivalent and return model is less problematic (Christie, 1987). The criticism do not prevent price model to persist (Barth, 1991; Harris, Lang and Möller, 1994; among others).

\subsection{Value relevance of earnings and book value}

Studies on information value relevance conducted mixed results in different economic sectors. Using price and return models and data from US markets, some studies found that earnings and book value are largely irrelevant in wireless communication industrial sector (Amir and Lev, 1996). The incremental value relevance of earnings is declined and that of book value is increased in the industrial and services sectors (Francis and Schipper, 1999), while a weak association has been found between these accounting variables and market values (Lev and Zarowin, 1999).

Using price model, earnings are more value relevant in US companies than in German industrial and services companies (Harris et al., 1994). Book value is more value relevant than earnings in UK services and industrial sectors (Vardavaki and Mylonakis, 2007) and in Australian companies (Whelan, 2004). The value relevance of book value has increased in Korean industrial and service sectors (Gee-Jang, 2009) and in Indonesian sectors (Suwardi, 2009), while earnings have been found to be irrelevant (Gee-Jang, 2009). According to Bao (2004), both earnings and book value are value relevant in seven Asian markets (Hong Kong, Malaysia, Singapore, Thailand, Indonesia, the Philippines and Korea). In Jordan, few studies have examined the value relevance of the accounting information using price model (Hadi, 2005) and return model (Anandarajan and Hasan, 2010). Their samples showed that earnings are value relevant. Consistent with previous studies in different markets, it is expected for this study that the value relevance of earnings and book value relative to the both valuation models will be increased.

However, we confirm with what Ota (2010) argued in that there is no definite solution or demonstration for the inconsistent results between the price and return models. In the absence of the definite solution, it is beneficial to combine both price and return models and permit more definitive inferences (Kothari and Zimmerman, 1995). Employing the both models is the most suitable response although this may lead to indistinct conclusions (Ota, 2010).

\section{Financial reporting in Jordan}

Since 1988 Jordan has became a member of the board of International Accounting Standards Committee (IASC). So Jordan relies on International Accounting Standards (IASs) including IASs and International Financial Reporting Standards (IFRS) that are issued by International Accounting Standards Board (IASB) which make Jordan moves out of the confined local accounting requirements to the fold of the international arena (Al-Jajawy and Noor, 2003). 
Although IASs have been adopted in Jordan, there is no doubt that Jordanian accounting environment needs to be developed in terms of strengthening the governance corporation with companies and the accountants and non-accountants' quality and training (Al-Jajawy and Noor, 2003). Actually, based on the accounting standards, an apparent lack of transparency has been observed in Jordan (Wallace and Shoult, 2004). This will be exacerbated by loosen regulation and lacking of business practices uniformity. It can be concluded that Jordan had made progress towards fiscal transparency, but still it was not sufficient (Anandarajan and Hassan, 2010).

Jordan had a limited accounting practice. This is because of the deficiency in recording transactions that satisfy only the outdated law requirements with no set form for financial statements. Indeed, Jordan suffered from many weaknesses in accounting regulation as the other developing countries did (Al-Akra et al., 2009). From the above discussion, we can notice that these limitations lead Jordanian financial reporting to yield confused information about firm value in ASE. To reduce this confusion, the current study will examine the value relevance of earnings and book value of equity to indicate whether they have the ability to reflect the firm value in Jordan since no study has been found in this country that examined the value relevance of these variables relative to price and return models.

\section{Hypotheses development and methodology}

\subsection{Hypotheses development and models}

While the value relevance of different accounting variables has been widely tested in developed stock exchanges relative to price or return models, few studies in developing stock exchanges include the two models in one study. Therefore, this study tries to examine the value relevance of earnings and book value of equity relative to the price and return models for Jordanian industrial firms. So, the study's first hypothesis will be;

H1a: Earnings are value relevant relative to price model.

H1b: Earnings are value relevant relative to return model.

Examining the association between the accounting information and firm value demands a valuation model. Recently, the most spread valuation model is built on Ohlson model (Barth, 2000; Barth et al, 2001; Ota, 2003, 2010). Ohlson model expressed the firm value as a function of earnings and book value. Depending on this formulation, the price and return models are drawn and they became the most extremely used regression models in value relevance studies. While the share price has been regressed on earnings and book value of equity in the price model, the stock return has been regressed on earnings (book value) and change in earnings (change in book value) in the return model (Ota, 2010) to indicate their ability to explain the variance in share price and return.

In order to test $\mathrm{H} 1$, the price and return models that will be used are;

$$
\begin{gathered}
\mathrm{P}_{\text {it }}=\beta 0+\beta 1 E P S{ }_{i t}+\mathrm{e}_{\text {it }} \\
\mathrm{R}_{\text {it }}=\varphi 0+\varphi 1 \mathrm{EPS}^{\mathrm{it}}+\varphi 2 \Delta \mathrm{EPS}_{\mathrm{it}}+\mathrm{e}_{\mathrm{it}}
\end{gathered}
$$

where for firm $i$ at the end of a year $t, P_{i t}$ is share price; $R_{i t}$ is share return; $E P S_{i t}$ is earnings per share; $\Delta E P S$ it is change in earnings per share and $\mathrm{e}_{\mathrm{it}}$ is a random error term.

The second hypothesis relative to price model will be;

H2a: Book value is value relevant relative to price model.

Other accounting variables have been employed in return model to replace or to be added to earnings in many studies. For example Francis, Schipper and Vincent (2005) used dividends and change in dividends individually and in a combination with earnings and change in earnings in return model. For the purposes of this study, book value and change in book value will be hypothesized as below;

$\mathrm{H} 2 \mathrm{~b}$ : Book value is value relevant relative to return model.

To test $\mathrm{H} 2$, the price and return models that will be used are;

$$
\begin{gathered}
\mathrm{P}_{\text {it }}=\lambda 0+\lambda \text { B BVPS }_{\text {it }}+\mathrm{e}_{\text {it }} \\
\mathrm{R}_{\text {it }}=\mu 0+\mu 1 \text { BVPS }_{\text {it }}+\mu 2 \Delta \text { BVPS }_{\text {it }}+\mathrm{e}_{\text {it }}
\end{gathered}
$$

where BVPS ${ }_{\text {it }}$ is book value of equity per share and $\triangle \mathrm{BVPS}$ it is change in book value of equity per share for firm $i$ at the end of a year $t$. other variables are defined before.

Consequently, in the next step, the analysis will continue to test the value relevance of the combined earnings and book value of equity relative to the both models. So, the third hypothesis will be; 
H3a: Combined earnings and book value is value relevant relative to price model.

H3b: Combined earnings and book value is value relevant relative to return model.

To test the value relevance of the combined earnings and book value (H3), the price and return models that will be used are;

$$
\begin{gathered}
\mathrm{P}_{\text {it }}=\omega 0+\omega 1 \mathrm{EPS}_{\mathrm{it}}+\omega 2 \mathrm{BVPS}_{\mathrm{it}}+\mathrm{e}_{\mathrm{it}} \\
\mathrm{R}_{\mathrm{it}}=\delta 0+\delta 1 \mathrm{EPS}_{\mathrm{it}}+\delta 2 \Delta \mathrm{EPS}_{\mathrm{it}}+\delta 3 \mathrm{BVPS}_{\mathrm{it}}+\delta 4 \Delta \mathrm{BVPS}_{\mathrm{it}}+\mathrm{e}_{\mathrm{it}}
\end{gathered}
$$

where all variables are defined before.

The above regression models are widely employed in prior research to examine the value relevance of the accounting variables (Harris et al., 1994; Collins, Pincus and Xie, 1997; Pirie and Smith, 2008 among others). According to Pirie and Smith (2008), an initial research design involving pooled and annual regressions has been used with a basic empirical model that links share price (and return) with the two main accounting variables (earnings and book value of equity). This approach is widely used in the literature, thus it will be adopted in this study.

\subsection{Sample and data selection}

Study's sample is the Jordanian industrial firms listed in ASE. The data is collected from the database that is published by Amman Stock Exchange Information Center (ASEIC). Sample period starts from 1992 and ends on 2002. All Jordanian industrial firms with available data for the selected study's variables are included and the share price, return and other accounting variables are represented as values in Jordanian dinar (JD) per share at the financial year end. Total of 198 firms-years and (1188) observations-years (18 firms * 6 variables * 11 years) will enter the analysis to obtain the requested findings.

\section{Empirical results}

To run the regressions analysis, its assumptions will be checked for the study's variables and data. Descriptive statistics will be done to ensure the normality of the sample population distribution. We will link share price and return with the earnings, book value individually and in a combination to estimate the annual and pooled results to indicate the value relevance of these variables relative to price and return models.

\subsection{Regression assumptions and descriptive statistics}

Normality, linearity, homoscedasticity, correlation and multicollinearity assumptions have been checked for the study's variables and raw data. We found that share price and the change in book value have Kurtosis values well up and down \pm 2 which suggests a non-normal distribution for these two variables. To eliminate the non-normal distribution, transformation process has to be done (Pallant, 2007). We found that logarithm (LOG10) transformation method is suitable to transform share price and change in book value of equity non-normal distribution into a normal one (refer to Appendix).

The descriptive statistics are reported in $<$ Table 1 $>$. Sample's valid and missing data, mean, standard deviation, minimum and maximum values are reported for the share price and return (as dependent variables) earnings, change in earnings, book value and change in book value (as independent variables). (Note 1) We missed data for change in book value. Totally, the remained observations for all variables are (1128) observations. From this table, it can be observed that standard deviation values (except that for return) are well below 3 which suggest the absence of the outliers (Pallant, 2007).

\section{Insert Table 1 here}

\subsection{Regression results and discussion}

The value relevance of the accounting information has been tested using annual and pooled data. We examine Hypotheses (1,2 and 3) by regressing earnings and book value individually and in a combination on share price/return to determine the value relevance of these variables. For this purpose, regression models 1 to 6 have been applied. $<$ Table $2>$ indicates the pooled regression results.

\section{Insert Table 2 here}

We conclude that both earnings and book value are value relevant in all 11 yearly regressions relative to price models (1 and 3). Earnings are value relevant in 10 out of 11 yearly regressions and book value in 2 out of 11 yearly regressions relative to return models ( 2 and 4$)$. Both earnings and book value are value relevant in the pooled sample relative to the two valuation models $(1,2,3$ and 4$)$. The value relevance of earnings is increased relative to both price and return models (models 1 and 2). This result is consistent with Hadi (2005) and 
Anandarajan and Hasan (2010) respectively. The value relevance of book value is increased relative to price model while it is declined relative to return model (models 3 and 4). This results is consistent with Francis and Schipper (1999) and Ely and Waymire (1999) who concluded the same results for the both models. Changes in earnings and book value are value relevant in 2 and 9 out of 11 yearly regressions respectively supported by the pooled sample (models 2 and 4 ).

These results support H1a, H1b, H2a and H2b. This indicates that both earnings and book value have the ability to reflect the variance in market value of equity. The results show that earnings are strongly relevant in both valuation models. This is reflected by the high coefficients on earnings. This might be explained by that investors rely on earnings since they contain information that has been reflected in share price before releasing the earnings which are perfectly predictable (Francis and Schipper, 1999).

As it was expected, the results indicate that the value relevance of earnings individually is increased relative to both price and return models, likewise the value relevance of book value relative to price model. The results are inconsistent with Ramesh and Thiagarajan (1995) who concluded that the value relevance of earnings is declined over time and Amir and Lev (1996) who found that earnings and book value are largely irrelevant. Inconsistency has been found between our result and other studies that concluded a decline in the value relevance of earnings and an increase in the value relevance of book value (Barth, Beaver and Landsman, 1997; Berger, Ofek and Swary, 1996; Burgstahler and Dichev, 1997; Collins et al., 1997; Francis and Schipper, 1999; Ely and Waymire, 1999). Our results are inconsistent with Harris et al. (1994), Whelan (2004) and Vardavaki and Mylonakis (2007) who concluded that book value is more value relevant than earnings or with other studies that found book value to be value relevant while earnings are not (Gee-Jang, 2009).

For the combined earnings and book value relative to the price model (5), earnings are value relevant in 8 out of 11 yearly regressions as well as in the pooled sample. Book value is value relevant in 8 out of 11 yearly regressions but not in the pooled sample. As a result, the value relevance of earnings is increased, while book value is irrelevant. Relative to return model (6), earnings are value relevant in all yearly regressions and book value in 9 out of 11 yearly regressions supported by the pooled sample. As a result, the value relevance of earnings is increased, while that of book value is declined. Changes in earnings and book value are irrelevant in the pooled sample although they are relevant in 4 and 2 out of 11 yearly regressions respectively (model 6). These results support $\mathrm{H} 3 \mathrm{~b}$ but not $\mathrm{H} 3 \mathrm{a}$.

$R^{2}$ values and the significant $F$-statistics suggest that the six models are fitted the data well in testing the hypotheses. This implies that earnings and book value of equity individually are value relevant relative to both price and return models. The results of $<$ Table $2>$ show that the $R^{2}$ values for the price model are greater than those for the return model. This is consistent with many studies (Harris et al., 1994; Francis and Schipper, 1999; Lev and Zarowin, 1999; Ely and Waymire, 1999). This indicates that the explanatory power of earnings and book value individually is greater in explaining the variance in share price than in share return, while in contrast, the explanatory power of the combined earnings and book value is much greater in explaining the variance in share return than in share price.

In total, the differences in results between price and return models from testing the three hypotheses might be explained by that (a) the two models sometimes yield inconsistent results (Ota, 2010), (b) price model is less biased and economically return model has less serious problems than price models (Kothari and Zimmerman, 1995), (c) as Francis and Schipper (1999) concluded, the decline in value relevance relative to return model could be resulted by the volatility increasing of market returns within the sample period or (d) the source of the inconsistency might be just for the period (1992 to 2002) in ASE. Overall, the paper conducted a difference in the results between price and return models in ASE as a developing market as well as those in developed market.

\section{Summary and conclusion}

The paper examined the value relevance of earnings and book value of equity individually and in a combination by employing Ohlson model (1995) relative to price and return models for Jordanian industrial firms including (1128) observations/years within the period 1992 to 2002. This paper contributes to the valuation literature in extending the valuation theory by examining the value relevance of the accounting information relative to the price and return models in an emerging market from Middle East region. Also, the paper contributes to ASE in strengthening the accounting practice in Jordan.

The value relevance of earnings is increased relative to the two valuation models, while that of book value is declined relative to return model. Combining earnings with book value increased the value relevance of earnings and insignificantly the value relevance of book value relative to price model, while it increased the value relevance of earnings and declined that of book value relative to return model. 
The study faced some limitations. The study's data is collected to include only companies with available data for the selected sector, variables and years (1992 to 2002). Also, the current study couldn't compare its results with any of previous studies related to ASE. Future research is called to employ both price and return models to prove or disprove our results by extending sample size, periods and sectors. Also it is called to focus on examining the value relevance of accounting information relative to both valuation models in ASE alone or across developing or developed countries to enrich academic research and increase the knowledge in this area.

\section{Acknowledgement}

The authors thank external reviewers and the editor for their helpful comments and suggestions.

\section{References}

Al-Akra, M., Ali, M., and Marashdeh, O. (2009). Development of accounting regulation in Jordan. The International Journal of Accounting, 44 (2), 163-186. http://dx.doi.org/10.1016/j.intacc.2009.03.003

Alford, A., Jones, J., Leftwich, R., and Zmijewski, M. (1993). The relative informativeness of accounting disclosures in different countries, Journal of Accounting Research, 31, 183-223. http://dx.doi.org/10.2307/2491170

Al-Jajawy, T., and Noor, A. (2003). International accounting standards and the Jordanian environment: The requirements of harmonization and application. Research Journal of Aleppo University, 35 (1), 1-21.

Amir, E., and Lev, B. (1996). Value-relevance of nonfinancial information: The wireless communications industry. Journal of Accounting and Economics, 22(1-3), 3-30. http://dx.doi.org/10.1016/S0165-4101(96)00430-2

Anandarajan, A., and Hasan. I. (2010). Value relevance of earnings: Evidence from Middle Eastern and North African countries. Advances in Accounting, Incorporating Advances in International Accounting, 26 (2), 270-279. http://dx.doi.org/10.1016/j.adiac.2010.08.007

Bao,Y. (2004). The value relevance of accounting information: Evidence from Asian markets. A dissertation (Ph.D). Kent State University-Graduate School of Manangement.

Barth, M. (1991). Relative measurement errors among alternative pension asset and liability measures. The Accounting Review, 66, 433-463. http://dx.doi.org/10.1111/1467-629X.00033

Barth, M. (2000). Valuation-based accounting research: Implications for financial reporting and opportunities for future research. Accounting and Finance, 40, 7-31.

Barth, M., Beaver, W., and Landsman, W. (1997). Valuation characteristics of equity book value and net income: Tests of the abandonment option hypothesis. Working paper, Stanford University, Stanford, CA.

Barth, M., Beaver, W., and Landsman, W. (2001). The relevance of the value relevance literature for financial accounting standard setting: Another view. Journal of Accounting and Economics, 31, 77-104. http://dx.doi.org/10.1016/S0165-4101(01)00019-2

Berger, P., Ofek, E., and Swary, I. (1996). Investor valuation of the abandonment option. Journal of Financial Economics, 42, 257-287. http://dx.doi.org/10.1016/0304-405X(96)00877-X

Burgstahler, D., and Dichev, I. (1997). Earnings, adaptation, and equity value. The Accounting Review, 72, 187-215.

Chen, C., Chen, S., and Su, X. (2001). Is accounting information value-relevant in the emerging Chinese stock market. Journal of International Accounting, Auditing and Taxation, 10, 1-22. http://dx.doi.org/10.1016/S1061-9518(01)00033-7

Christie, A. (1987). On cross-sectional analysis in accounting research. Journal of Accounting and Economics, 9, 231-258. http://dx.doi.org/10.1016/0165-4101(87)90007-3

Collins, D., Pincus, M., and Xie, H. (1997). Equity valuation and negative earnings: The role of book value of equity. Working paper, University of Iowa, Iowa City, IA.

Ely, K., and Waymire, G. (1999). Accounting standard-setting organizations and earnings relevance: longitudinal evidence from NYSE common stocks, 1927-1993. Journal of Accounting Research, 37, 293-318. http://dx.doi.org/10.2307/2491411

Francis, J., and Schipper, K. (1999). Have financial statements lost their relevance? Journal of Accounting Research, 37(2), 319-352. http://dx.doi.org/10.2307/2491412 
Francis, J., Schipper, K., and Vincent, L. (2005). Earnings and dividend informativeness when cash flow rights are separated from voting rights. Journal of Accounting and Economics, 39, 329-360. http://dx.doi.org/10.1016/j.jacceco.2005.01.001

Gee-Jung, K. (2009). The value relevance of book values, earnings and cash flows: Evidence from Korea. International journal of business and management, 4(10), 28-42.

Gonedes, N., and Dopuch, N. (1974). Capital market equilibrium, information production, and selecting accounting techniques: Theoretical framework and review of empirical work. Journal of Accounting Research, 12, 48-130. http://dx.doi.org/10.2307/2490499

Hadi, M. (2005). Information content of cash flows data: Evidence for Jordon. Working paper. Kuwait University.

Harris, T. S., Lang, M., and Möller, H. P. (1994). The Value Relevance of German Accounting Measures: An Empirical Analysis. Journal of Accounting Research, 32, 2, 187-209. http://dx.doi.org/10.2307/2491281

Kothari, S., and Zimmerman, J. (1995). Price and return models. Journal of Accounting and Economics, 20, 155-192. http://dx.doi.org/10.1016/0165-4101(95)00399-4

Landsman, W., and Magliolo, J. (1988). Cross-sectional capital market research and model specification. The Accounting Review, 64, 586-604.

Lev, B., and Ohlson, J. (1982). Market based empirical research in accounting: A review, interpretations, and extensions. Journal of Accounting Research, 20, 249-322. http://dx.doi.org/10.2307/2674685

Lev, B., and Zarowin, P. (1999). The boundaries of financial reporting and how to extend them. Journal of Accounting Research, 37, 353-385. http://dx.doi.org/10.2307/2491413

Ohlson, J. (1995). Earnings, book values and dividends in equity valuation. Contemporary Accounting Research, 11 (2), 661-687. http://dx.doi.org/10.1111/j.1911-3846.1995.tb00461.x

Ota, K. (2003). The impact of price and return models on value relevance of studies: A review of theory and evidence. Accounting Research Journal, 16(1), 6-20.

Ota, K. (2010). The value relevance of management forecasts and their impact on analysts' forecasts: Empirical evidence from Japan. Abacus, 46(1), 28-59. http://dx.doi.org/10.1111/j.1467-6281.2009.00299.x

Pallant, J. (2007). SPSS survival manual. (3 ${ }^{\text {rd }}$ ed.). McGraw Hill Education.

Pirie, S., and Smith, M. (2008). Stock prices and accounting information: Evidence from Malaysia. Asian Review of Accounting, 16 (2), 109-133. http://dx.doi.org/10.1108/13217340810889924

Ramesh, K., and Thiagarajan, R. (1995). Inter-temporal decline in earnings response coefficients. Working paper. Northwestern University, Evanston, IL.

Suwardi, E. (2009). The dynamic relationship between accounting numbers and share prices on the Jakarta Stock Exchange. International Review of Business Research Papers, 5 (5), 16-24.

Vardavaki, A., and Mylonakis, J. (2007). Empirical evidence on retail firms' equity valuation models. International Research Journal of Finance and Economics, 7, 104-119.

Wallace, J., and Shoult, A. (2004). Doing business with Jordan. U.K: Kogan Page Publishers.

Whelan, C. (2004). The impact of earnings management on the value-relevance of earnings and book value: A comparison of short-term and long-term discretionary accruals. A dissertation (Ph. D). Faculty of Business, Bond University. Australia.

\section{Note}

Note 1. Data about Skewness and Kurtosis before and after transformation is reported in Appendix 1. 
Table 1. Descriptive statistics

\begin{tabular}{|l|llllll|}
\hline & PRICE & RETURN & EPS & BVPS & $\Delta$ EPS & $\Delta$ BVPS \\
\hline N Valid & 197 & 198 & 198 & 198 & 198 & 139 \\
Missing & 1 & 0 & 0 & 0 & 0 & 59 \\
Mean & .5230 & 12.2421 & .3503 & 2.7951 & .0237 & -.9482 \\
Std. Deviation & .36022 & 8.53204 & .30590 & 2.00507 & .22518 & .53742 \\
Minimum & -1.10 & -21.44 & -.20 & .10 & -.69 & -2.00 \\
Maximum & 1.38 & 45.53 & 1.35 & 9.51 & .87 & .63 \\
\hline
\end{tabular}

EPS: earnings per share; BVPS: book value of equity per share; $\triangle \mathrm{EPS}$ : change in earnings per share; $\triangle \mathrm{BVPS}$ : change in book value of equity per share.

Table 2. Pooled regression sample results

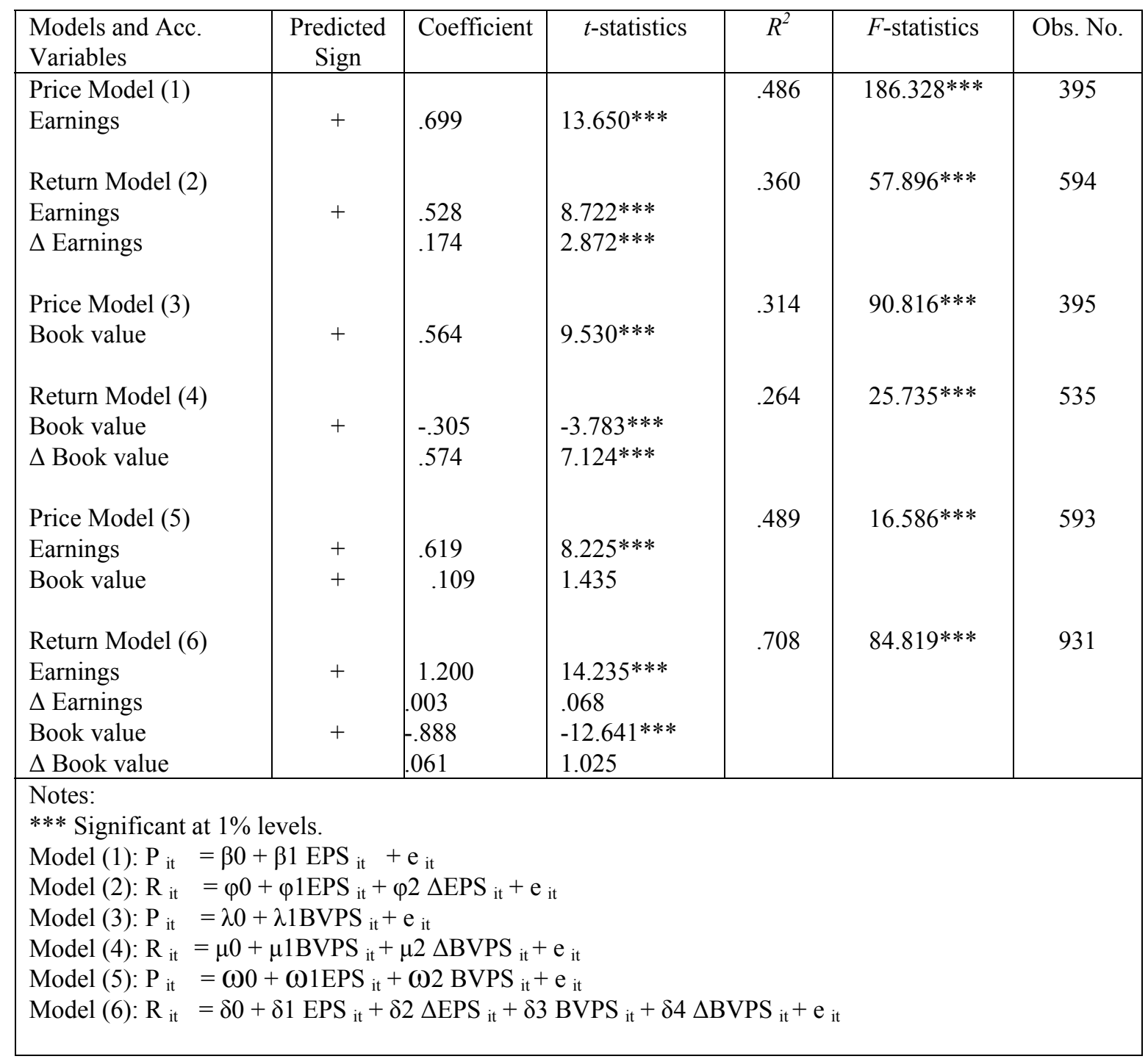




\begin{tabular}{|c|c|c|c|c|c|c|c|}
\hline \multicolumn{8}{|c|}{$\begin{array}{l}\text { Appendix: Results of transformation process } \\
\text { Before transformation }\end{array}$} \\
\hline \multicolumn{8}{|c|}{$\begin{array}{l}\text { Appendix: Results of transformation process } \\
\text { Before transformation }\end{array}$} \\
\hline & & PRICE & RETURN & EPS & BVPS & $\Delta \mathrm{EPS}$ & $\triangle B V P S$ \\
\hline \multirow[t]{2}{*}{$\mathrm{N}$} & Valid & 198 & 198 & 198 & 198 & 198 & 198 \\
\hline & Missing & 0 & 0 & 0 & 0 & 0 & 0 \\
\hline Ske & & 1.845 & .223 & 1.012 & 1.723 & .473 & -.827 \\
\hline Std & f Skewness & .173 & .173 & .173 & .173 & .173 & .173 \\
\hline & & 4.680 & 1.973 & .363 & 2.313 & 2.870 & 15.628 \\
\hline & f Kurtosis & .344 & .344 & .344 & .344 & .344 & .344 \\
\hline \multicolumn{8}{|c|}{ After transformation } \\
\hline & & PRICE & RETURN & EPS & BVPS & $\triangle \mathrm{EPS}$ & $\triangle \mathrm{BVPS}$ \\
\hline \multirow[t]{2}{*}{$\mathrm{N}$} & Valid & 197 & 198 & 198 & 198 & 198 & 139 \\
\hline & Missing & 1 & 0 & 0 & 0 & 0 & 59 \\
\hline & & -.437 & .223 & 1.012 & 1.723 & .473 & .025 \\
\hline & f Skewness & .173 & .173 & .173 & .173 & .173 & .206 \\
\hline & & 1.230 & 1.973 & .363 & 2.313 & 2.870 & -.202 \\
\hline Std & f Kurtosis & .345 & .344 & .344 & .344 & .344 & .408 \\
\hline
\end{tabular}

